\title{
Understanding Tourists' Willingness-to-Pay for Rural Landscape Improvement and Preference Heterogeneity
}

\author{
Li Cong ${ }^{1}$, Yujun Zhang ${ }^{1, *}$, Ching-Hui (Joan) Su ${ }^{2}$, Ming-Hsiang Chen ${ }^{3,4,5}$ and Jinnan Wang ${ }^{1}$ \\ 1 School of Landscape Architecture, Beijing Forestry University, Beijing 100083, China; \\ lisacong@bjfu.edu.cn (L.C.); 18519090360@163.com (J.W.) \\ 2 Department of Apparel, Events, and Hospitality Management, College of Human Sciences, Iowa State \\ University, Ames, IA 50011-1078, USA; joansu@iastate.edu \\ 3 School of Hospitality Business Management, Carson College of Business, Washington State University, \\ Pullman, WA 99164-4742, USA; ming-hsiang.chen@wsu.edu \\ 4 College of Tourism and Landscape Architecture, Guilin University of Technology, Guilin 541006, China \\ 5 School of Business Administration, Anhui University of Finance and Economics, Bengbu 233030, China \\ * Correspondence: yjzhang@bjfu.edu.cn
}

Received: 5 November 2019; Accepted: 3 December 2019; Published: 7 December 2019

\begin{abstract}
With the vigorous development of urbanization and rural tourism, the landscape of villages and towns has undergone tremendous changes under the influence of policies and industries. In order to avoid irreversible changes in the local heritage landscape and promote local sustainable development, it is necessary to strengthen the attention and research on the rural recreation landscape. This research examines the value of rural landscape recreation by applying the choice experiment method (CEM) to a suburban area in Sichuan, China. Mixed logit models were adopted in examining tourists' willingness-to-pay (WTP) for rural landscape improvement and preference heterogeneity. An assessment of the rural landscape's recreational value was made using the compensating surplus calculation method. Results reported are of four important landscape elements: ecological environment, rural life and associated productive landscape, rural housing, and service landscape, ranked by tourists from high-to-low. A major finding of the research is that an increase in rural tourism is dependent upon improvements to landscape elements. The results of this research can provide policymakers with valuable information necessary to develop a successful plan to attract and increase tourism in rural areas of China.
\end{abstract}

Keywords: rural landscape; rural tourism; recreational value; choice experiment; China

\section{Introduction}

Rural tourism (RT) has been widely recognized as an effective catalyst for rural socio-economic regeneration [1-5]. Although China is still recognized as the most populous agrarian society in the world [6], rural tourism in China is a relatively recent phenomenon, with only about 20 years of development [7]. The Chinese government has always placed primary importance on meeting the challenge of rural social and economic development, supporting and promoting rural tourism through promotions and events. In 1993, the China National Tourism Administration (CNTA) introduced the first "China Urban and Rural Tourism Year" and another in 2006. The CNTA created a series of RT-promoted activities which offered financial incentives as well as government policy support as a means to incorporate farm diversification into tourism.

At the same time, China's rapid urbanization has created a social and economic phenomenon that has resulted in the equally rapid conversion of land use from rural to urban with a negative impact 
on agricultural landscapes [8,9]. According to predictions made by the construction department of China's central government, the level of urbanization will reach $50 \%$ by the end of 2020 with an urban population of 1.5 billion [10]. Migration to urban areas from 1996-2008 resulted in a 135.2 million decrease in China's rural population [11]. Predictably, the yearly migration of 10 million people during the 1990s from China's rural areas resulted in rapid urbanization [12].

When considering the course of rural development in China, the argument can be made that most development, the result of market and economic forces, is not planned. As a result, the traditional rural landscape has been greatly transformed. Many new rural communities now contain pseudo-classic dwellings and houses placed as barracks which has a negative visual impact on the rural landscape. In addition, commercial towns and villages with pseudo-classic cottage and garden-style facilities have also appeared on the landscape [13]. As a result of these changes, the rural heritage has been degraded, due to the disappearance of traditions and rural characteristics, which can be compared to similar occurrences in the United States decades ago [14].

Rural tourism is increasing significantly in China, but has been largely ignored by the international academic community, despite its scale and development potential [15]. An estimate of the willingness-to-pay (WTP) for improvements to the rural landscape is the policy objective of this study [16]. By employing a multi-attribute valuation approach, attribute values and the subsequent marginal effects can be estimated to give a more detailed picture of the drawbacks and benefits associated with various policy plans. In addition, the use of a stated preference methodology where the estimates of existence benefits are sought includes the public benefit as well as the non-market nature of rural landscapes. Therefore, this study employs a discrete-choice experiment technique [16-19].

Daugstad maintains that the rural landscape is a vitally important component of rural tourism in comprising visually engaging components such as open fields, orchards, herds of livestock, and people engaged in rural activities [20]. In this paper, we seek to gain further understanding of the features of a rural landscape in a Chinese context and explore the significance of the findings in regard to rural tourism development in China. Using choice experiment method (CEM) as a method of analyzing and China as a study subject, empirical findings from this paper will contribute to the literature on the valuation of landscape attributes, and further provide a framework for China's policy management in a role in rural development. Accordingly, four specific research objectives are addressed in this paper: (1) identification of the contribution of different elements of a rural landscape for its recreational value; (2) identification of tourists' preference for different rural landscape elements; (3) assessment of the recreational value of a rural landscape in financial terms; (4) examination of the potential for the choice experiment method to elicit values in the context of Chinese agro-tourism.

\section{Literature Review}

\subsection{Rural Tourism}

International academic interest in rural tourism can be traced back to the 1950s [21]. Over time, increasing outputs have gained attention from different countries worldwide for rural tourism development [22-27]. According to Sharpley and Roberts [28], the nature of rural tourism is multifaceted and contains interdisciplinary themes such as the role(s) of state, regional and local government; and the transfer of social capacity and multiple stakeholder involvement. The geographical spread is mostly Europe, North America, and Australasia, while Chinese perspectives are few [15]. Norwegian agricultural authorities consider rural tourism as a vital component in the use of agricultural practices in plans for landscape maintenance diversification [29]. The negotiation of the differing perspectives and perceptions of the principals involved in the rural tourism landscape-tourists, farmers and operators-is another key feature in Norwegian agricultural tourism development [20].

In terms of understanding the landscape context for rural tourism in China, the word "landscape" has a variety of connotations and definitions in different disciplines [20]. For geographers, landscape is a kind of terrain, or comprehensive natural geographical area [20]. However, an artist may consider 
landscapes as an expression or as the representation of an object. From an architectural perspective, the landscape is often seen in an urban context; the structure or background of a group of buildings [30]. From an ecological point of view, a landscape may be seen as an ecosystem [31]. Tourism experts often regard the landscape as a resource for tourism [32] but Tuan [33] wrote: "Landscape... is not to be defined by itemizing its parts. The parts are subsidiary clues to an integrated image. Landscape is such an image, a construct of the mind and of feeling (p. 89)." Accordingly, landscape as perceived by one person is not necessarily the same as perceived by another [32,33]. Yu considers the landscape as being complex, occurring at different scales, and including constructed items, road systems, and ecological systems [34].

Rural tourism and rural landscape research have been explored in the Chinese context by Li and Chen et al. [35]. Wang and Guo et al. [36] summarized the relationship between rural tourism and rural landscape (Figure 1) and pointed out that the natural or semi-natural components of a rural landscape have been ignored in the development of rural tourism in China while such elements form a significant part of tourism development in Western countries. The classification of rural landscape in China can be explored from two perspectives. The first is to distinguish the material and intangible elements based on whether the element objectively exists or not, then subdividing the elements according to entities and functions. For example, Xia considered the rural landscape to be constituted of natural landscape, material elements, and intangible elements [37]. The second perspective is to define a landscape as a complex of entity material elements and spiritual connotations, then distinguishing the material and intangible elements. Accordingly, Gao and Wang [38] have divided rural tourism resources into three categories: the agricultural landscape, the settlement landscape, and the folk culture landscape.

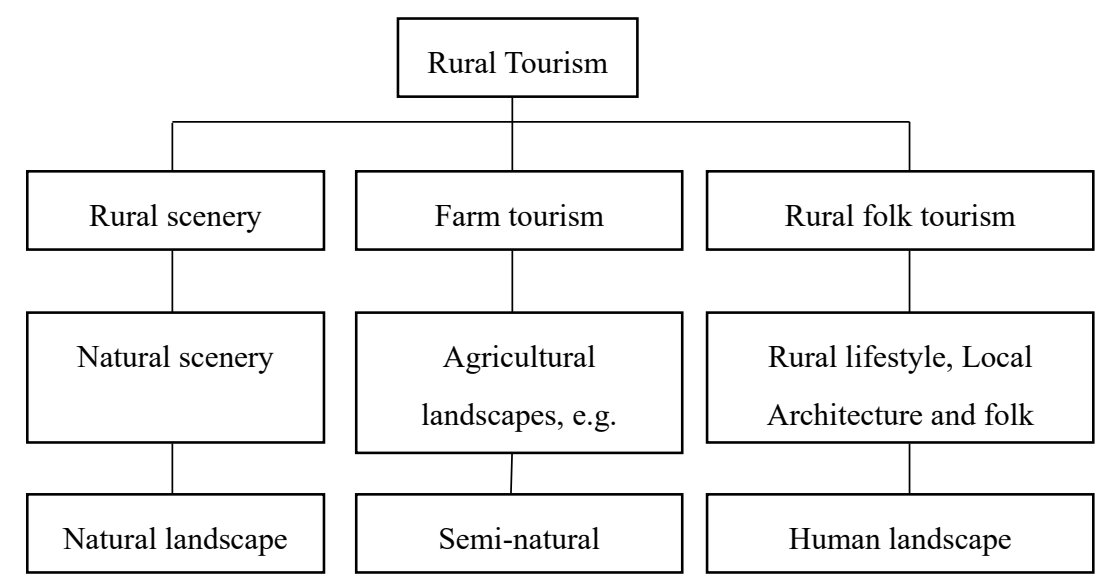

Figure 1. The relationship between rural tourism and rural landscape [36].

Liu and Wang put forward an indicator system to evaluate rural landscapes for five aspects: quality, sensitivity, accessibility, compatibility, and livability [39]. Wang and Liu pointed out that the core content of rural landscape planning in China is centered on integral rural images and suitable zones for industry planning, land utilization planning, theme landscape, and settlement landscape planning [40]. Xie and Liu et al. [41] went on to establish an index system that includes economical value, social value, ecological value, and aesthetics to evaluate rural landscape. Additionally, seven future scenarios for rural landscape evolution are identified by Fang and Liu using natural, landscape, socioeconomic, and spatial indicators. These types are (1) production landscape, (2) tourism landscape, (3) natural landscape, (4) agriculture-nature balanced landscape, (5) nature-tourism balanced landscape, (6) agriculture-residence balanced landscape, and (7) rights competed landscape. Further to these rural landscape scenarios, each type of rural landscape has different locations, compositions, and functions [42].

During China's period of modernization, the rural landscape, in the context of tourism, was considered primarily as an economic tool for rural development [15]. However, rural tourism has 
also been identified as a catalyst for social harmony and as a means to generate new socialist rural communities [43]. And as the Chinese government has recognized, tourism can also aid in the preservation of ethnic cultures [15]. Employing Sharpley and Roberts's three themes as an analytical framework, Gao and Huang et al., in an evaluation of China's rural tourism policies and practices, concluded that failure to include rurality as an integral component in the development of rural tourism could misdirect that development $[15,28]$. As a result, the agro-tourism industry's sustainability could be negatively affected. In line with a rural tourism perspective, the rural landscape considered in this paper is defined as embracing the ecological landscape, productive landscape, and rural life landscape. This view differs from the city or town landscape, as it occurs in a comprehensive natural and rural geographical area, which is potentially attractive to tourists.

\subsection{Landscape Evaluation}

Landscape evaluation, a form of landscape appraisal, involves the identification and assignment of value or importance to the qualities, desirability, and features of a particular landscape, as a method of establishing an economic or monetary value on the landscape. There is a dearth of literature on landscape evaluation, which uses a range of valuation techniques. The choice experiment approach is one commonly taken in Western research [16,44]. Bergland [45] used the CEM to evaluate agricultural landscape in Norway. Hanley et al. [46] used CEM to study the value of rivers after the improved ecological environment. Birol et al. [47] employed CEM to assess the non-use value of Greek wetlands. Most CEM studies address rural environmental protection, and these studies have also played an important role in the landscape management of policymakers.

The attributes in the specific study are related to the development or upgrading of rural landscapes. For example, rural quality of life, rural employment, rural dwellings, hedges, or bushes. One of the most common attributes is woodlands, followed by wildlife. In addition, local cultural heritage is also frequently found in research, and there are different expressions in different studies. For example, Dominguez-Torreiro and Solino [48] elaborated on the local cultural heritage as a monument, traditional culture, and Colombo and Hanley [49] interpreted it as a specific architecture, local cultivation, and traditional animal husbandry. It is worth mentioning that Campbell, in estimating economic gains derived from rural landscape improvements in Ireland, originally applied a discrete-choice experiment [16]. The CEM approach is thus being increasingly used in the field of environmental valuation, tourism, and recreation studies [50-53]. Ayala and Hoyos et al. systematically reviewed different studies in regard to the valuation of rural landscapes using choice experiments, pointing out that comprehension in landscape studies should be addressed in future research, with particular emphasis given to alternative survey design, varying numbers of attributes, and scenario presentation [54].

The ecological landscape refers to the landscape pattern, topography, flora and fauna, derived phenology, and ecological culture of the village. The ecological landscape provides the basic condition for the development of villages, and in combination with geographical characteristics, provides a macro basis for village cultural development. The rural life landscape refers to the landscape architecture, or structure, which includes the functions of living, exchange, and transport, as well as the connotations of religion or folklore, thus making it the support and expression of lifestyle. Productive landscapes comprise farmland, breeding farms, ranches, mines, and other material production fields. The productive landscape of traditional villages is dominated by primary industries such as farming, forestry, animal husbandry, and fishing, which will obviously mean a high degree of dependence on ecological conditions.

The service landscape refers to accommodation and recreational facilities, and guidance systems that mainly serve extraneous tourists. These features have a close connection with landscape features, although the service landscape component has more emphasis on leisure tourism services. Each type of landscape can be divided into material landscape and intangible landscape sub categories. Material landscape refers to the physical; one that is objective reality and can be seen, touched, or sensed. 
Intangible landscape refers to non-substantial, multi-cultural landscape, although sometimes there is no discernable boundary between the material and intangible landscape.

In the model estimation part, most studies use random coefficient logit regression, or hybrid logit regression, a few scholars have adopted the traditional multinomial logit model. Because individuals' choices in landscape value assessment are often based on their hobbies, experiences, attitudes, and cognitions, and because the landscape is complex and subjective, models that allow for heterogeneity are more appropriate. There is gap on research about the value of Chinese rural landscapes using the CEM.

\section{Methodology}

\subsection{Study Site}

Sam Shing Huaxiang is located in the southeast of Chengdu Jinjiang, part of an urban green space, at the east of Longquanyi District and south of Shuangliu County (Figure 2). Sam Shing Huaxiang includes five scenic tourist areas: Huaxiang Farmers' House (Hongsha village), Happy Plum Forest (Happy village), Jiangiia Farmland (Jiangjiayan village), Dongli Daisy Garden (Fuma village), and Moonlight over the Lotus Pond (Wanfu village).

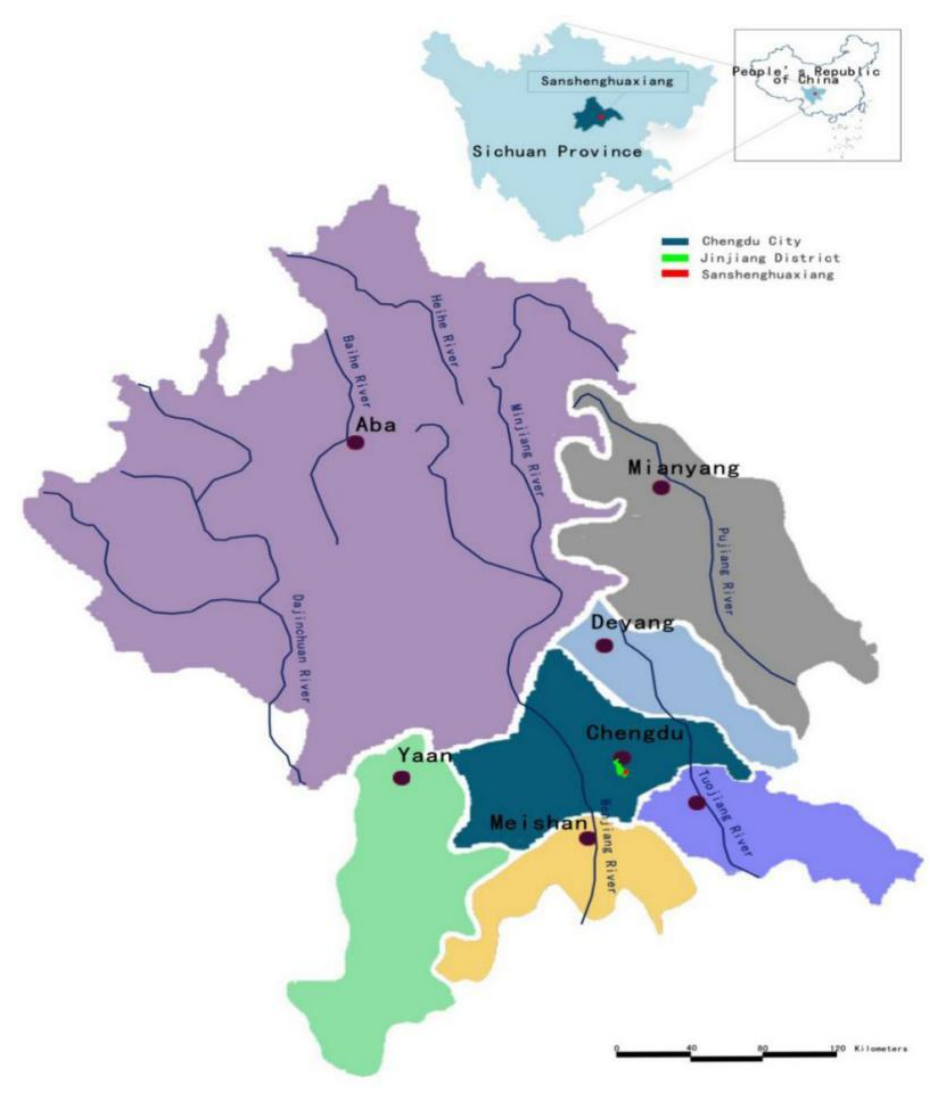

Figure 2. Location of Sam Shing Huaxiang.

In 2003, Hongsha village held the first flower expo in Sichuan and built the Flower Township Farmers' Home. The attraction was rated as a national AA level tourist area and one of the first national agricultural tourism demonstration sites (Table 1). In 2006, Sam Shing Huaxiang successfully became the national AAAA level scenic tourist area, and hosted China's first rural tourism festival. The 5A-level tourist scenic spot is assessed by the National Tourism Administration (now integrated into the Ministry of Culture and Tourism) and is assessed by the National Tourism Scenic Area Quality Rating Committee. The 5A level is the highest level of China's tourist attractions, representing the Chinese world. The assessment is mainly based on three major rules; service quality and environmental 
quality (1000 points); landscape quality (100 points); tourist opinions (100 points). The rationale for using Chengdu Sam Shing Huaxiang in Sichuan Province as a case study is based on the following criteria: (1) Sam Shing Huaxiang is located in the suburbs of Chengdu, where the rural landscape (Figure 3) and urban elements coexist; (2) in Sam Shing Huaxiang, rural tourism associated with flower sales and sightseeing developed early and is representative of domestic rural tourism; (3) it is located in the suburbs of Chengdu, where tourist traffic flow is significant and a good sample size can be guaranteed.

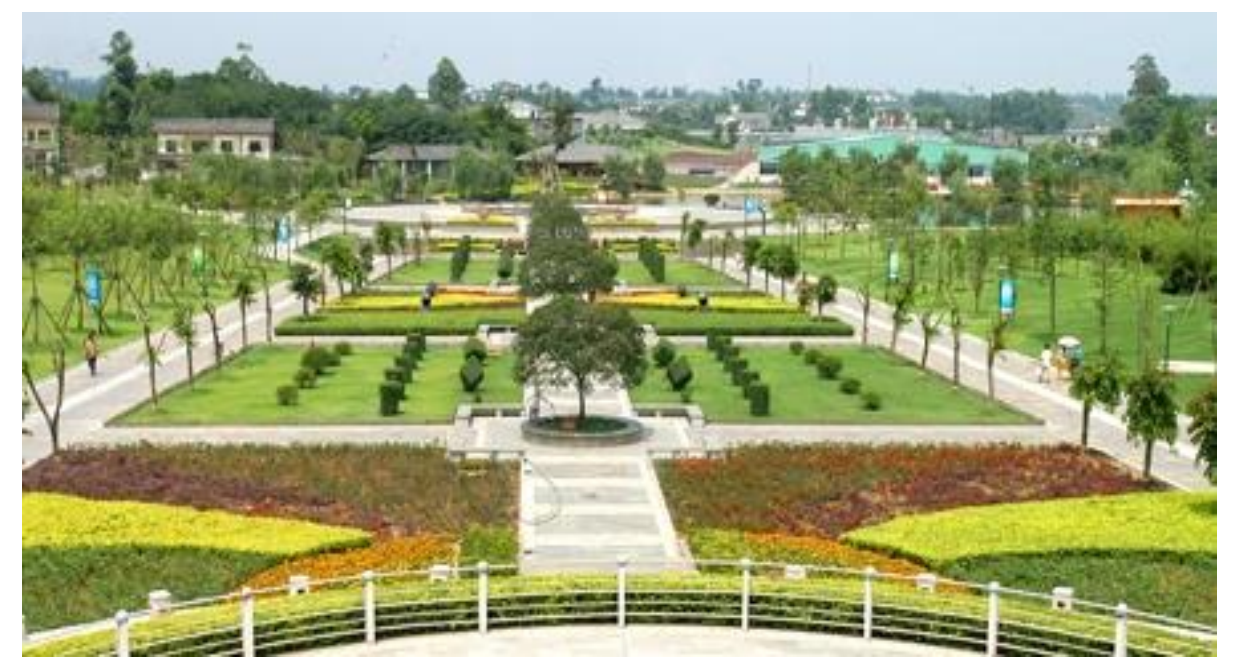

Figure 3. Partial ecological landscape of Sanshenghuaxiang. (Source: http://www.enjoycd.com/xiuxian/ news_list.asp?id=258).

Table 1. Data from features village of Sam Shing Huaxiang in 2017.

\begin{tabular}{cccccc}
\hline Project & $\begin{array}{c}\text { Huaxiang Farmers' } \\
\text { House }\end{array}$ & $\begin{array}{c}\text { Happy Plum } \\
\text { Forest }\end{array}$ & $\begin{array}{c}\text { Moonlight over the } \\
\text { Lotus Pond }\end{array}$ & $\begin{array}{c}\text { Dongli Daisy } \\
\text { Garden }\end{array}$ & $\begin{array}{c}\text { Jiangjia } \\
\text { Farmland }\end{array}$ \\
\hline $\begin{array}{c}\text { Population } \\
\text { Farm stay }\end{array}$ & 3010 & 3200 & 3100 & 3400 & 4200 \\
$\begin{array}{c}\text { Per capita } \\
\text { annual net } \\
\text { income (yuan) }\end{array}$ & 100 & 102 & 50 & 25 & 10 \\
Village features & Flower expo & Plum festival & Lotus festival & Daisy festival & Land adoption \\
\hline
\end{tabular}

Source: Data from local government of Jinjiang District.

\subsection{Questionnaire Design}

We used questionnaires to collect data on tourists' evaluation of the Sam Shing Huaxiang rural landscape. The questionnaire was designed in four parts: visitor behavior, cognition of landscape elements in villages and towns, policy choices for improvement of village and town landscapes, and personal information. The selection of the village and town landscape improvement policy is a key part of this study. Before the questionnaire was filled in, the investigators first used 1-3 minutes to show the tourists the graphic card of the Sanshenghua Township Landscape Enhancement Plan, explaining the promotion strategies and different levels of each landscape property. They allowed visitors to enter the simulation situation as soon as possible. In turn, visitors chose a plan or chose a status quo plan based on different landscape enhancement policies and the increased cost.

In the choice experiment survey section, the attributes of different landscape improvement schemes were first set from the perspective of landscape classification, followed by consideration of comprehension and independence, and then focus group method of assembling students, teachers, tourists, local residents, and managers. Through the discussion of the focus group, five attributes of 
ecological environment, rural dwellings, rural production landscape, service landscape, and willingness to increase consumption were determined, including four landscape attributes and one economic attribute. Four of the landscape attributes were divided into two levels: "good" and "very good." In addition, since there are no admission fee for Sanshenghua Township, the economic property cannot be measured by the increase or decrease of the admission price, and because each visitor comes in at a single time (including transportation, catering, accommodation, amusement, etc.), Therefore, the attribute was set to the value that the visitor is willing to pay after the landscape is upgraded, that is, the willingness to pay.

The willingness to pay is the core of the choice experiment model. Visitors express their preferences by weighing the changes in each attribute and using a certain degree of willingness to pay. In the survey, the cue board informed visitors that they need to consider the economic situation such as personal income to choose the payment value. The lower limit of the payment amount is 0 yuan, that is, the current consumption level is not willing to increase. The upper limit of the payment amount was obtained in the pre-survey and set to 100 yuan. We then used a choice experiment to evaluate the recreational value of major elements in rural landscape and various categories of landscape evaluation, such as the level of natural appearance and tourists' impressions of the rural lifestyle (Tables 2 and 3, and Figure 4). The overall recreational value of Sam Shing Huaxiang was then derived from the calculated result of landscape element values.

The consideration of policy options to improve the rural landscape is a key part of this study. Figure 4 (indicative landscape enhancement plan) is an example of a choice task presented to respondents during the discrete-choice experiment. Considering that there is no admission fee currently charged and Chinese are resistant to paying tax, the additional payment applied was to use additional fees for the visitors and not use a taxation approach as other researchers have done so [46]. A WTP component refers to all expenditures within the destination including dining, entertainment, souvenirs etc. The payment would then be collected by the merchant from local citizens and part of the fee would then be collected by the government. Such additional pricing could also increase the income of local people and provide them with more money to improve the landscape of interest.

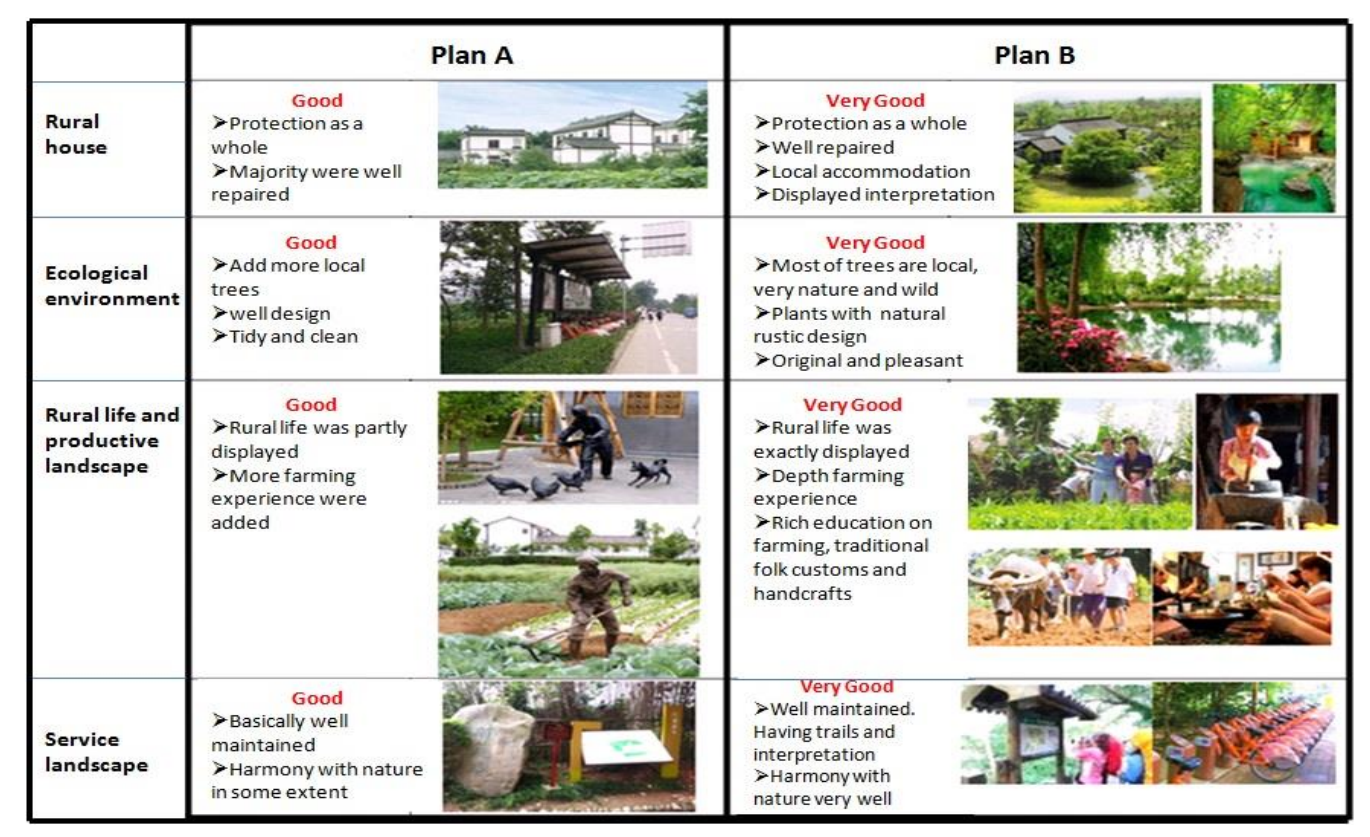

Figure 4. Example of the visual aids used to explain the attributes. 
Table 2. Attributes and their levels used in the choice experiment.

\begin{tabular}{|c|c|c|}
\hline Attributes & Levels & Description \\
\hline \multirow{3}{*}{ Ecological environment } & Very good & Most of trees are native, natural settings \\
\hline & Good & Add more local trees, well designed, tidy and clean \\
\hline & Status quo & Looks more like a garden, basic, clean and tidy \\
\hline \multirow{3}{*}{ Rural house } & Very good & $\begin{array}{l}\text { Mostly in its original state, well maintained, local } \\
\text { accommodations, interpretation display }\end{array}$ \\
\hline & Good & Mostly in its original state, maintained \\
\hline & Status quo & Original state, but poorly repaired \\
\hline \multirow{3}{*}{$\begin{array}{l}\text { Rural life and productive } \\
\text { landscape }\end{array}$} & Very good & $\begin{array}{c}\text { Rural landscape well displayed, deeply engaged in } \\
\text { farming activity, education, and traditional folk } \\
\text { handicrafts. }\end{array}$ \\
\hline & Good & Rural landscape display, some farming activity \\
\hline & Status quo & Rural housing, less farming activity \\
\hline \multirow{3}{*}{ Service landscape } & Very good & $\begin{array}{l}\text { Good facilities, comprehensive interpretation, } \\
\text { walking trails and perceived harmony with nature }\end{array}$ \\
\hline & Good & Good facilities, retains rural feel \\
\hline & Status quo & Facilities not well developed, some are too modern \\
\hline \multirow{5}{*}{$\begin{array}{l}\text { Willingness to pay (per person, per } \\
\text { visit) }\end{array}$} & 0 & Prefer not to pay more \\
\hline & 25 & Willing to pay additional 25 yuan \\
\hline & 50 & Willing to pay additional 50 yuan \\
\hline & 75 & Willing to pay additional 75 yuan \\
\hline & 100 & Willing to pay additional 100 yuan \\
\hline
\end{tabular}

The choice experiment survey explored attribute settings in different parts of the landscape followed by a focus group that included students, teachers, tourists, local residents, and managers. As a result of the focus group discussion, five attributes were decided: ecological environment, local houses, rural productive landscape, service landscape, and additional payment for services, and four landscape attributes were explored at the "good" and "very good" levels (Table 2). These levels were selected to be broad for the following reasons. Firstly, because it is feasible to use a perception of degree and visual aids to express the change of attributes. Secondly, in the tourist's mind, landscape preferences incline towards perception, rather than the actual extent of vegetation cover or water areas. Faced with vegetation coverage rate preferences of $10 \%, 30 \%$, and $50 \%$, tourists are more likely to choose the higher value without understanding the ecological context of a certain value. Thirdly, the information cards contained interpretation of different levels of landscape perception.

Table 3 is an example of a selection set in the questionnaire. This selection set provides three options to choose from regarding the Sam Shing Huaxiang landscape enhancement plan to be introduced within the next three years. Plan 1 enhances rural life, the productive landscape, and the service landscape and requires an expenditure of an additional 100 yuan per person. In Plan 2, Sam Shing Huaxiang's ecological and environmental protection will be improved at a cost of an additional 50 yuan per person. A status quo plan was also included, with no added cost attached. In the survey, investigators reminded respondents that the additional costs were hypothetical and that a choice was to be made according to the situation.

From the attributes and levels of Table 3, we will get $64(2 \times 2 \times 2 \times 2 \times 4)$ different combinations. Due to the abundant combinations of visitor selections, this study uses a fractional factorial experimental design and adopts the "select design" function in Data Exploration JMP10 developed by the SAS Institute. The aim is to exclude implausible alternatives and dominated alternatives in the selection sets and ultimately retain 42 selection sets (each selection set contains two enhancing plans and a status quo plan), while the 42 selection sets are divided into seven editions each containing six selection sets (Table 3). Namely, each visitor does only six selection sets to ensure statistical validity. 


\subsection{Questionnaire Distribution}

Fifty questionnaires were distributed in the pre-survey for the initial impression of data and problem modification. The upper limit of additional willingness to pay was calculated to be 100 yuan. Formal questionnaires were randomly distributed for seven days, between 1 August and 7 August 2013 across five villages in the Sam Shing Huaxiang area. Five specific sites with a large flow of tourists in five villages were chosen and a convenience sampling strategy was used. Samplings were made at various times (noon and evening) for one day. The questionnaires were completed and collected from respondents, one-on-one, and at the site. A small token, a fan, was used to encourage participation.

Before being asked to complete the questionnaire, investigators spent 1-3 minutes giving visitors information and a card with a graphic of a possible Sam Shing Huaxiang landscape enhancement plan. This helped explain the strategies and different levels of possible enhancements to various landscape attributes. This approach introduced visitors to a variety of landscape enhancement proposals early in the planning process. Visitors then were asked to choose a plan based on preferences for landscape enhancements and the subsequent cost. The respondents were then able to derive information about the scenario and improvement strategies (Figure 4). Also, respondents were reminded that they could base their choice upon their personal income. A total of 490 questionnaires were distributed and 482 questionnaires were completed, 13 of which were invalid, with a final response rate $95.9 \%$. The one-on-one interview approach, on site collection, and a useful small gift (the weather was hot) yielded a high valid collection rate.

\subsection{Model Variable Coding and Definition}

The mixed logit model was used for that it allows all forms of correlation, including scale heterogeneity [55]. In this study, the software STATA12 was used to build the mixed logit model in regard to analysis of survey results. As shown in Table 4, the dependent variable in the model is defined as $\mathrm{CHO}$, and in each set of selections, if one option is selected, it is 1 , and if it is not selected, it is 0 . There are 10 independent variables, including 5 attribute variables and 5 individual variables. The individual variables include gender, education level, average family monthly income, frequency of visits, and current expenses. In addition, CID and PID are defined to represent the selection set number and personal number, respectively, to meet the requirements of the hybrid logit model construction.

The mixed logit model can completely solve the limitation of satisfying the independence of irrelevant alternatives (IIA) hypothesis and better explain the consumer's choice behavior. The mixed logit model was introduced. In the construction of mixed logit model 1 (which is intended to explain consumer choice behavior), the variable is set to be random and normally distributed. To further analyze the reason for the attribute variables' heterogeneity, selected variables and individual variables were combined to generate new cross variables, including those in the model, and then set as fixed coefficients. The model is named as mixed logit model 2. Because the increased WTP is used to calculate the standard deviations of other variables with WTP, its coefficient is also set as a fixed coefficient [56], and the model is named as mixed logit model II.

Coefficients of selected variables are derived from the regression model. With any two of these coefficients $\beta_{m}$ and $\beta_{n}$, marginal rate of substitution (MRS) of attributes $m$ and $n$ that corresponded with this coefficient can be obtained and calculated as:

$$
\mathrm{MRS}_{\mathrm{mn}}=-\frac{\beta_{\mathrm{m}}}{\beta_{\mathrm{n}}} .
$$

If WTP substitutes for $n$, we can get the attribute m's marginal willingness to pay (MWTP), which is also called the implicit price in some studies [57]. It demonstrates the price people are willing to pay for an improvement in the level of the considered attribute. This corresponds with increased WTP in this study. When calculating the Sam Shing Huaxiang recreational value, it is important to use the 
compensating surplus (CS) method, as it can represent the monetary value to consumers due to the improvement of a condition. According to Hanemann [58], the CS equation can be expressed as:

$$
\mathrm{CS}=\frac{\operatorname{In} e^{v_{j 0}}-\operatorname{In} e^{v_{j 1}}}{-\beta_{v p}}
$$

where $\beta_{v p}$ refers to the coefficient of WTP, and $v_{j 0}, v_{j 1}$ refer to two conditions after attribute $j$ changed. If all attributes are changed, the formula is simplified as:

$$
\mathrm{CS}=\frac{v_{0}-v_{1}}{-\beta_{v p}} .
$$

\begin{tabular}{|c|c|c|c|c|c|c|}
\hline & $\begin{array}{c}\text { Local } \\
\text { Houses }\end{array}$ & $\begin{array}{l}\text { Ecological } \\
\text { Environment }\end{array}$ & $\begin{array}{l}\text { Rural Life and } \\
\text { Productive } \\
\text { Landscape }\end{array}$ & $\begin{array}{c}\text { Service } \\
\text { Landscape }\end{array}$ & Payment & Choice \\
\hline Plan 1 & Good & Good & Very good & Very good & 100 & $\sqrt{ }$ \\
\hline Plan 2 & Good & Very good & Good & Good & 50 & \\
\hline Status quo & Mediocre & Mediocre & Mediocre & Mediocre & 0 & \\
\hline
\end{tabular}

Table 3. Example of a selection set.

$\sqrt{ }$ Don't know and don't want to choose.

Table 4. Interpretation of the variables used in the model coding.

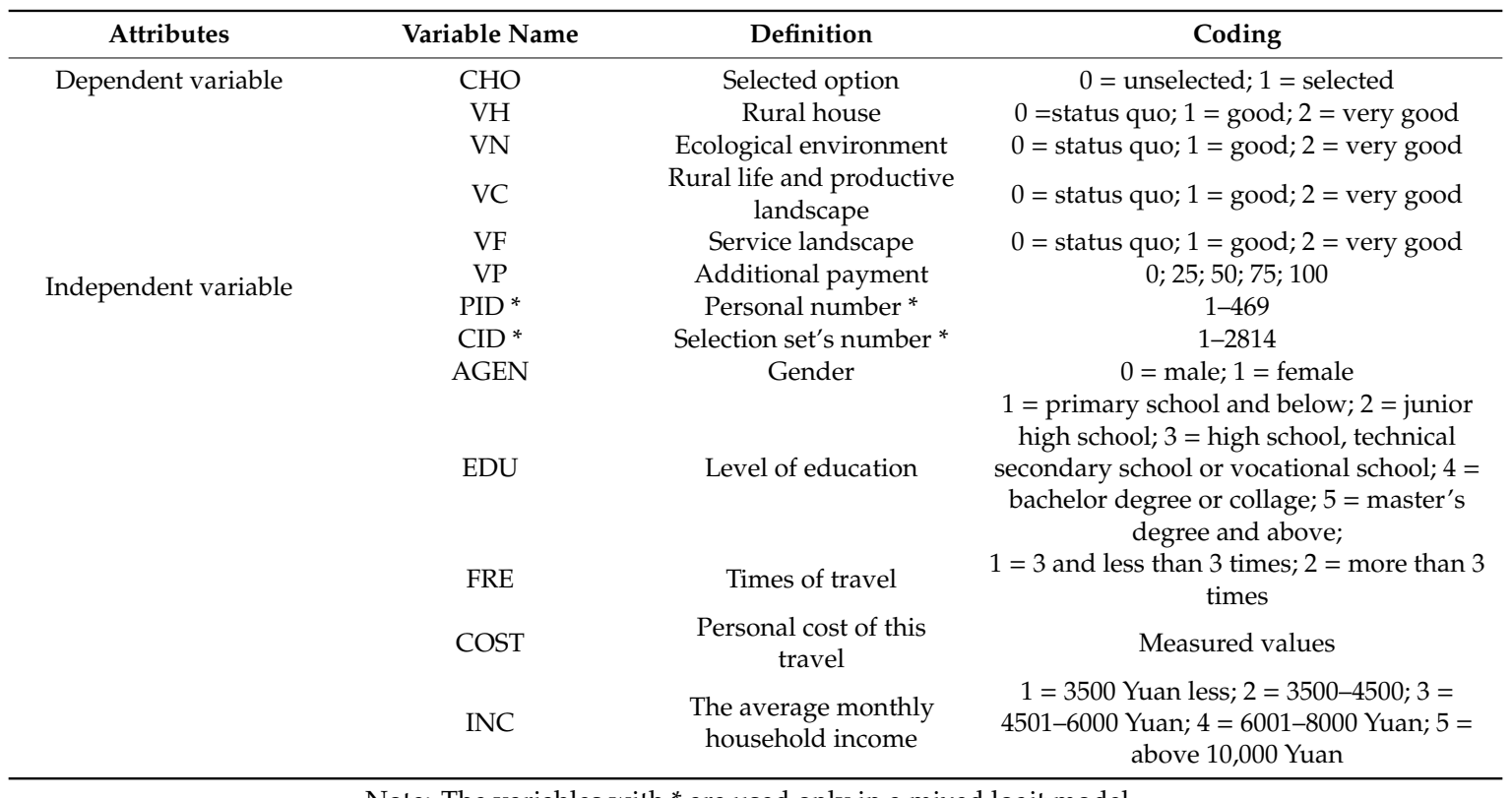

Note: The variables with * are used only in a mixed logit model.

\section{Research Results}

\subsection{Demographic Analysis}

An age structure of $18-45$ years accounted for $73.6 \%$ of the respondents with $82.3 \%$ of the respondents having a high school and undergraduate education. The lack of an entrance fee coinciding with the summer holiday period at Sam Shing Huaxiang is likely to explain the high level of student participation in the survey. Family income is mainly distributed between 3500-6000 yuan, which accounts for $45.2 \%$ of the respondents, while those with a family income below 3500 accounts for only $26.2 \%$. The main socioeconomic variables of the whole sample are indicated in Table 5. 
Table 5. Data of demographics of respondents.

\begin{tabular}{|c|c|c|c|}
\hline Variables & Categories & Frequency & Percentage \\
\hline \multirow{2}{*}{ Gender } & Male & 207 & 44.1 \\
\hline & Female & 262 & 55.9 \\
\hline \multirow{5}{*}{ Age } & $<18$ years & 45 & 9.6 \\
\hline & $18-30$ & 182 & 38.8 \\
\hline & $31-45$ & 163 & 34.8 \\
\hline & $46-60$ & 67 & 14.3 \\
\hline & $>60$ & 12 & 2.6 \\
\hline \multirow{5}{*}{ Education } & Primary school & 10 & 2.1 \\
\hline & Junior middle school & 40 & 8.5 \\
\hline & High middle school & 105 & 22.4 \\
\hline & Bachelor & 281 & 59.9 \\
\hline & Postgraduate & 33 & 10.6 \\
\hline \multirow{13}{*}{ Vocation } & Manager & 47 & 10.0 \\
\hline & Official & 57 & 12.2 \\
\hline & Professional & 21 & 4.5 \\
\hline & Teacher & 20 & 4.3 \\
\hline & Business/Service & 11 & 2.3 \\
\hline & Student & 101 & 21.5 \\
\hline & Police officer & 54 & 11.5 \\
\hline & Worker & 41 & 8.7 \\
\hline & Farmer & 32 & 6.8 \\
\hline & Freelancer & 74 & 15.8 \\
\hline & Unemployment/housewife & 1 & 0.2 \\
\hline & Retirement & 6 & 1.3 \\
\hline & Others & 4 & 0.9 \\
\hline \multirow{6}{*}{ Income } & $<3500$ Yuan & 123 & 26.2 \\
\hline & 3500-4500 Yuan & 105 & 22.4 \\
\hline & 4501-6000 Yuan & 107 & 22.8 \\
\hline & $6001-8000$ Yuan & 62 & 13.2 \\
\hline & $8001-10,000$ Yuan & 29 & 6.2 \\
\hline & $>10,000$ Yuan & 43 & 9.2 \\
\hline
\end{tabular}

\subsection{Sam Shing Huaxiang Landscape Evaluation}

Tourist preferences in regard to important elements in the rural landscape were measured according to a five-point Likert scale where the highest score is the most preferred situation. Figure 5, which represents indicators of rural landscape quality, shows that the scores of the various landscape elements are deemed as good, reflecting higher scores in regard to present landscape conditions. Scores representing rural landscape qualities of "away from the hustle and bustle of the city," "natural beauty of the landscape," and "sanitary conditions" all exceed four points, indicating that the natural/rural environment of Sam Shing Huaxiang is currently acceptable to tourists. The attributes of "residential characteristics," "food specialties," "festival features," and degree of "public service" facilities scored slightly lower. 


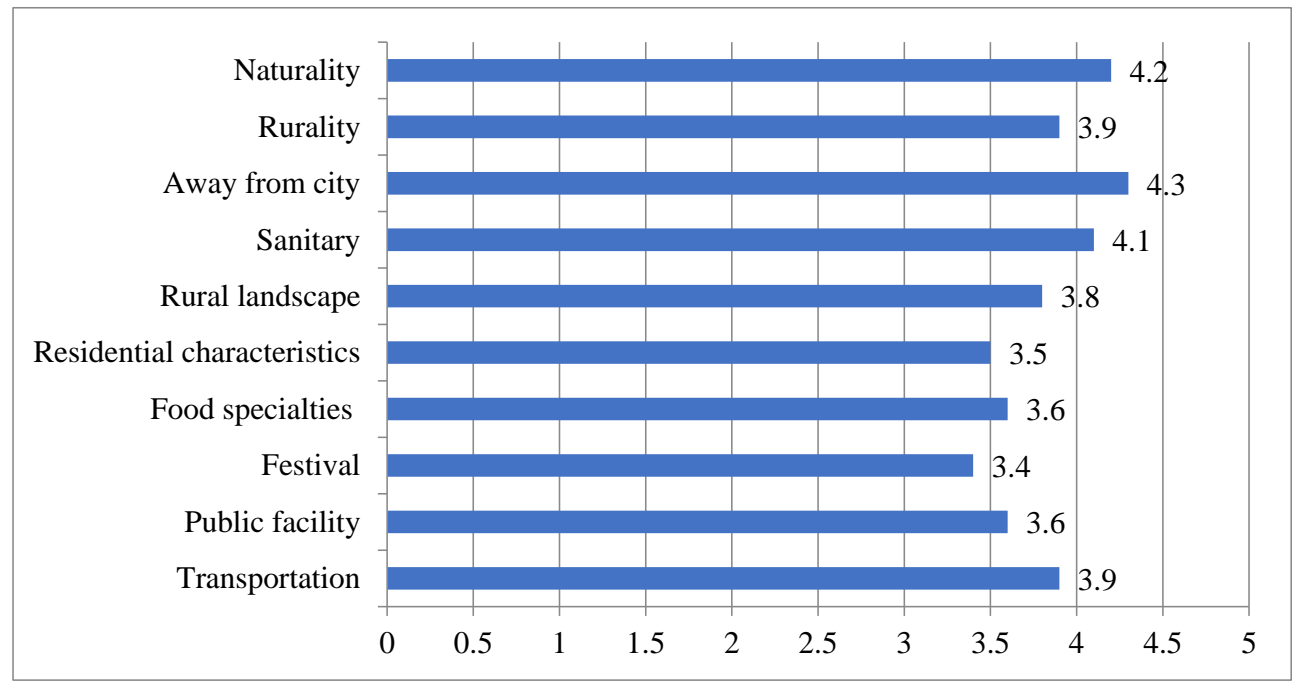

Figure 5. Satisfaction with current aspects of the landscape.

\subsection{Recreational Value Assessment}

We used the Halton extraction method in which $\mathrm{R}=100$, called mix logit command to get the results as indicated in Table $6[59,60]$. The model is found to be statistically significant with a Chi-squared statistic of 32.11 and Prob $>\mathrm{Chi}^{2}=0.0001$, thus the model fits well. Parameters including the "good" level and the "very good" level of ecological environment and WTP have the expected results and are statistically significant.

Table 6. Mixed logit model.

\begin{tabular}{|c|c|c|c|c|c|}
\hline \multirow[t]{2}{*}{ Attributes } & \multirow[t]{2}{*}{ Distribution Type } & \multicolumn{2}{|c|}{ Mean } & \multicolumn{2}{|c|}{$\begin{array}{l}\text { Standard Deviation of the } \\
\text { Random Parameters }\end{array}$} \\
\hline & & Coefficient & Standard Error & Coefficient & Standard Error \\
\hline Payment & Normal distribution & $-0.012 * * *$ & 0.001 & $-0.018^{* * *}$ & 0.002 \\
\hline $\begin{array}{c}\text { Ecological } \\
\text { environment: good }\end{array}$ & Normal distribution & $6.305^{* *}$ & 3.480 & 0.328 & 0.055 \\
\hline $\begin{array}{l}\text { Ecological } \\
\text { environment: very } \\
\text { good }\end{array}$ & Normal distribution & $4.213^{* *}$ & 2.321 & 0.023 & 0.052 \\
\hline \multirow{2}{*}{$\begin{array}{l}\text { Rural housing: good } \\
\text { Rural housing: very } \\
\text { good }\end{array}$} & Normal distribution & -5.342 & 3.340 & 0.245 & 0.051 \\
\hline & Normal distribution & -3.633 & 2.227 & -0.009 & 0.060 \\
\hline $\begin{array}{l}\text { Rural life and } \\
\text { productive } \\
\text { landscape: good }\end{array}$ & Normal distribution & 0.377 & 3.469 & -0.007 & 0.073 \\
\hline $\begin{array}{l}\text { Rural life and } \\
\text { productive } \\
\text { landscape: very } \\
\text { good }\end{array}$ & Normal distribution & 0.386 & 2.313 & 0.094 & 0.058 \\
\hline $\begin{array}{l}\text { Service landscape: } \\
\text { good }\end{array}$ & Normal distribution & -1.854 & 4.169 & 0.000 & 0.049 \\
\hline \multirow[t]{2}{*}{$\begin{array}{l}\text { Service landscape: } \\
\text { very good }\end{array}$} & Normal distribution & -1.102 & 2.780 & 0.001 & 0.045 \\
\hline & $\mathrm{Chi}^{2}(5)=32.11$ & ikelihood $=-$ & 7.098 & $\mathrm{hi}^{2}=0.0001$ & \\
\hline
\end{tabular}

Note: The standard deviation of a random parameter (payment) is closely related to odds ratios, and the negative standard deviation indicates that the possibility of a tourist's choice is lower than the possibility of non-choice. ** Significance at the $5 \%$ level. ${ }^{* * *}$ Significance at the $1 \%$ level.

The mixed logit model with interactions are shown in Table 7. 
Table 7. Mixed logit model with interactions.

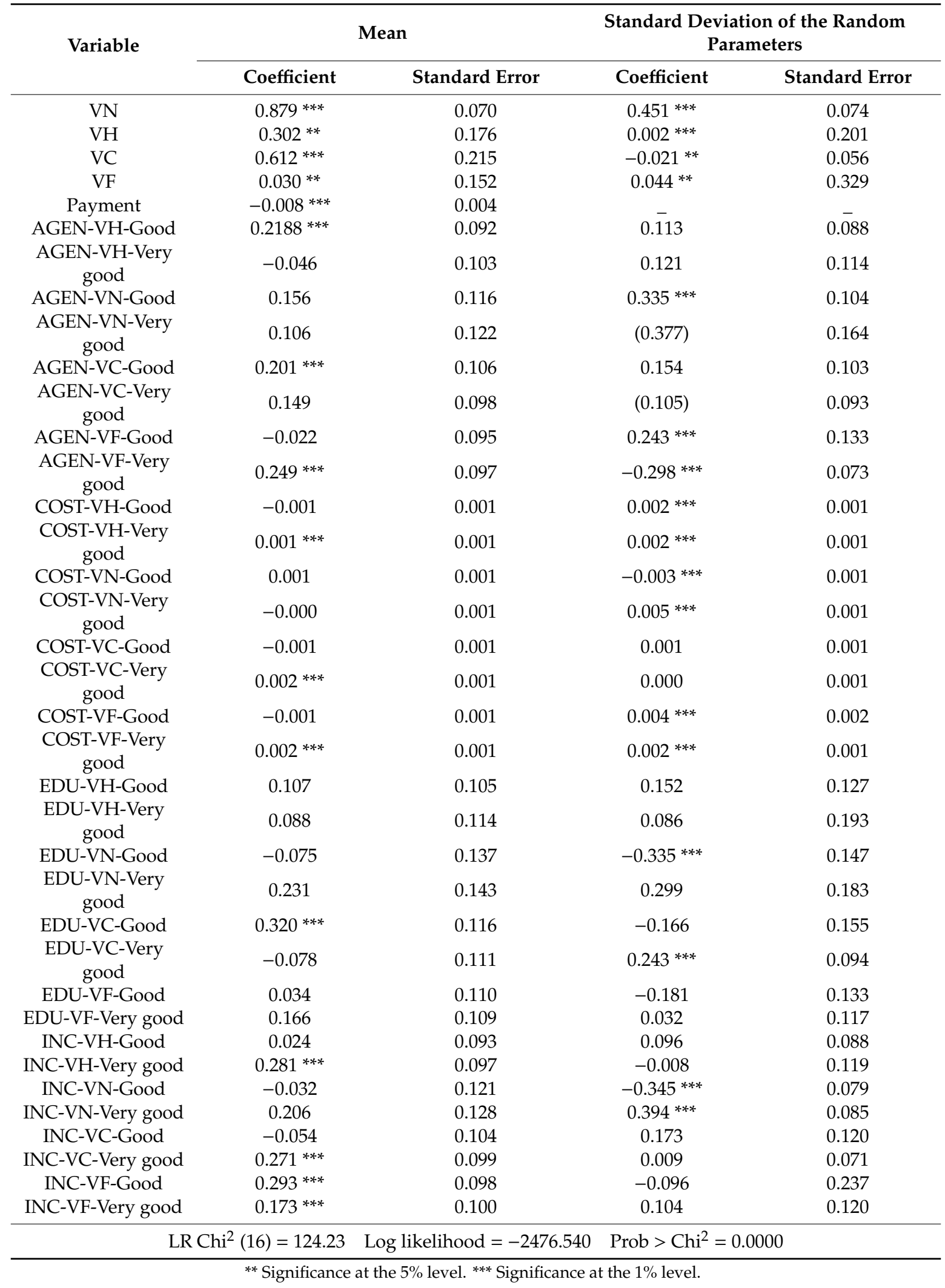

As can be seen from Table 7, in the mixed logit model $2 \mathrm{Prob}>\mathrm{Chi}^{2}=0.0000<0.001$, the model fits well. Table 7 reports a model which pools WTP for all the new interaction attributes. The new 
interaction attributes are distinguished by the inclusion of dummy variables with "good" and "very good" to differentiate the two levels of landscape improvement. An implied ranking of the rural landscape attributes can be deduced from these coefficients and "VN," "VH," "VC," and "VF" are ranked from high to low. Coefficient of payment in the results remains negative, which indicates the possibility of tourists' choice is less than the possibility of non-choice.

Among the cross variables of selected variables and individual variables, and the description of abbreviations (Table 4), the coefficient of AGEN-VH-Good, AGEN-VC-Good, and AGEN-VF-Very good are positive and statistically significant. Males are coded 1 and females, 2, which results reveal that more women than men prefer to improve the service landscape, enhance the local residential architecture landscape, and provide accommodation that reflects local culture and interpretation. Coefficients of COST-VH-Very good, COST-VC-Very good, and COST-VF-Very good are positive and statistically significant, indicating higher WTP at the very good level of different attributes. Coefficient of EDU-VC-Good is positive and statically significant, in that it indicates that tourists with higher education levels want to see improvements in rural life and productive landscapes. Coefficient of INC-VH-Very good, INC-VC-Very good, INC-VF-Good are positive and statistically significant, indicating that tourists with a higher than average monthly household income place higher demands on the Sam Shing Huaxiang service landscape and landscape facilities, as they have higher expectations for travel convenience and services. It is noteworthy that visitors who spend more are also more willing to pay more, but their willingness to improve the ecological environment is lower. Currently the ecological landscape in Sam Shing Huaxiang has met these tourists' needs, and they are more interested in the authentic rural life and productive landscape aspects of the study area.

\subsection{Tourists' WTP for Sam Shing Huaxiang}

The only significant variables in the utility model are "payment" and "ecological environment" as shown in Table 6. In this case, WTP estimates can only be derived for ecological environment. As can be seen from Table 8, in the mixed logit model I, ecological environment's MWTP is 73.6 yuan, representing that when other attributes remained unchanged, if the ecological environment is increased to the "very good" level as described in the questionnaire, visitors are, on average, willing to increase the pay 73.6 yuan.

\subsection{Sam Shing Huaxiang Recreational Value Estimates}

According to the formula (2), tourists' WTP per person per time under each model can be calculated (Table 8). Its value in the mixed logit model 2 shows that when Sam Shing Huaxiang's ecological environment, rural housing, rural life, and productive landscape and service landscape reach the optimal level, a visitor's WTP (per person per visit) increased to 348.9 yuan over the present average cost of 69.9 yuan, for a total WTP of 418.8 yuan. According to records from the Jinjian Tourism Bureau, the Sam Shing Huaxiang tourist area received 12 million visitors in 2012. Assuming that the number of visitors in 2013 remained unchanged, it can be concluded that under the different conditions of the two models in Table 8, the recreational value of Sam Shing Huaxiang in 2013 was between 4.7 billion yuan and 5.03 billion yuan.

Table 8. Marginal value of different landscape attributes, willingness-to-pay, and recreational value in different models.

\begin{tabular}{|c|c|c|c|c|c|c|c|}
\hline & \multicolumn{3}{|c|}{ Ecological Environment } & \multicolumn{2}{|c|}{ Increased WTP } & \multirow{2}{*}{$\begin{array}{l}\text { WTP } \\
\text { (Yuan) }\end{array}$} & \multirow{2}{*}{$\begin{array}{l}\text { Sam Shing Huaxiang Recreational Value } \\
\text { (One Hundred Million Yuan) }\end{array}$} \\
\hline & Coefficient & MWTP & Order & Coefficient & (Yuan) & & \\
\hline $\begin{array}{l}\text { Mixed logit } \\
\text { model } 1\end{array}$ & 0.898 & 73.600 & 1 & -0.012 & 321.8 & 391.7 & 47.0 \\
\hline $\begin{array}{l}\text { Mixed logit } \\
\text { model } 2\end{array}$ & 0.879 & 108.300 & 1 & -0.008 & 348.9 & 418.8 & 50.3 \\
\hline
\end{tabular}




\section{Conclusions and Discussion}

This research examines the value of rural landscape recreation by applying the choice experiment method to a suburban area in Sichuan, China. Through field investigation and questionnaire analysis, mixed logit models are constructed to understand tourists' willingness-to-pay for rural landscape improvement and preference heterogeneity. The following conclusions were obtained:

The value of rural tourism, a relatively recent phenomenon in China, has so far been primarily as an economic means for the development of rural areas during the country's modernization process $[14,28,43]$. Chengdu Plain and Sam Shing Huaxiang have developed a unique experience in agriculture, accumulating expertise in various stages of its history. Landscape as a kind of environmental goods has multiple values, and most of the villages and towns with good and characteristic landscapes have realized the economic transformation of their recreational value through the development of rural tourism. This research extends the case study for evaluating rural landscapes worldwide to China. An assessment of the rural landscape's recreational value was made using the compensating surplus calculation method. The CEM is an emerging method in environmental goods evaluation in recent years. It combines the research model adopted in the traditional marketing and transportation field and applies it to environmental property evaluation, and has advantages in attribute value research and effectiveness. This research further verified that CEM is an applicable method to evaluate environmental goods.

A major finding of the research is that an increase in rural tourism is dependent upon improvements to landscape elements. In the landscape assessment survey that comprised this study, elements such as a desire to "get away from the hustle and bustle of the city," experience the "natural beauty of the landscape," and the availability of sanitary services score higher than "residential characteristics," "food specialties," "festival features," and the degree of public service facilitation. Given that the mixed logit model releases the IIA restrictions can deal with the preference heterogeneity, it is an appropriate method used in this study to examine the situation and offer explanations. Developing rural life and landscape productive features are important because they condense the wisdom and art of generations of working people $[58,61]$. According to the results, tourists' valuation of landscape elements in high-to-low order is as follows: ecological environment, rural life and productive landscape, rural houses, and service landscape, which reflects the priority tourists place on natural attributes and rural properties in rural tourism. This finding verified that in order to achieve sustainable development, landscape element improvement should obey heterogeneity characteristics.

Mixed logit models were adopted in examining tourists' willingness-to-pay for rural landscape improvement and preference heterogeneity. Combined with the evaluation of the value of Sanshenghua Township, the current consumption level of tourists (69.9 yuan/person) and the willingness to pay for each landscape element to reach the best state (348.9 yuan/person) are still close to 5 times. The recreational value of Sam Shing Huaxiang in 2013 was between 4.7 billion yuan and 5.03 billion yuan. This finding has valuable hints for policymakers and destination marketing. Negotiation is required between the key players—-tour operators, tourists, and farmers (Daugstad [20])—each of whom differ in their values, views, and perception of landscape. While tourism traditionally encompasses recreational values and visual scenes, tourism providers can visualize other potential, for example, local food sources in the agro-tourism niche market, which could, in turn, strengthen farm-based economy and increase the viability of rural communities [20]. According to Pan [62] urban residents place the highest priority for rural tourism facilities on "natural simplicity" and "cleanliness," indicating that qualities such as "rural" and "natural" are more important than "luxury," "elegance," or urban images and experiences. For example, in Israel the return on investment into rural accommodation (about 37\%) is $13 \%$ higher than accommodations in the city [63].

In this paper, results reported are of four important landscape elements: ecological environment, rural life and associated productive landscape, rural housing, and service landscape, ranked by tourists from high-to-low. In this context, tourists are also encouraged to make a more in-depth use of the landscape in regard to environmental, natural, and architectural resources. The strategy in 
this context would be to allow visitors to gain knowledge and insight into rural wisdom, labor, and modes of production through various methods and activities such as rural recovery, symbolism, and/or explanation. This is in line, with the assertions of Sharpley and Jepson [64] who maintain that that rural tourism should not only work at a physical level but also within a deeper, more spiritual context. For example, Perales has shown that in Spain, tourists take advantage of what exists, including small "charming" hotels, small living rooms, and bedrooms on farms [27].

\section{Implications to Rural Tourism Development}

According to the findings of this research, several considerations are suggested for Sam Shing Huaxiang to further protect the rural landscape and to enhance the attractiveness of rural tourism to form a sustainable and healthy development mechanism. They are as follows:

Create development opportunities that build upon the core attraction of the rural landscape. Currently, Chengdu has established the direction to build a world-class garden city. The tourism industry is central to the success of such a project and will be key to help resolve the economic gap between urban and rural areas. Although Sam Shing Huaxiang is a model of rural tourism in Chengdu, perhaps for all of China, there is scope for further planning and development. For example, a large part of its tourism mode is still the traditional "farmhouse," which is similar to that of the competition nearby. This investigation shows that tourists place a lot of value on the ecological environment and the rural life and productive landscapes. With the progress of urbanization, the rural landscape is becoming increasingly scarce. Conversely, it also shows that there is value in the potential scarcity of the rural landscape. Accordingly, Sam Shing Huaxiang should focus on the protection of its ecological environment as well as the construction of rural life and the productive landscape in order to provide pleasant and authentically scenic surroundings where tourists can relax as well as learn. Through such an integrated process, Sam Shing Huaxiang could achieve the goals to improve sustainable development and rural tourism.

Protect the natural and rural components of the landscape and maintain a differentiated and graded investment. The Chinese government's guidance and investment is vital to achieving some of these objectives. However, it is important to note that substantive investment should not be made without adequate planning as there is a danger of unwanted outcomes resulting from poor consideration given to environmental factors and community needs. In promoting the development of urban and rural integration, the policy guidelines are suggested to pay attention to retaining the original features of the village, and improving the living conditions of the residents as much as possible in the original village form. In order to promote the sustainable development of villages and towns, the policy guidelines are suggested to protect local heritage, which includes villages, antique houses, neighborhoods, and gardening facilities. Sam Shing Huaxiang has been previously described as having a low proportion of native plants, and a high proportion of artificial gardens in its ecological environment. Increasing the number and protection of native plants, allocating resources, and encouraging biodiversity conservation are important strategies.

Create a wealth of experience and depth perception of the rural landscape by expanding the land adoption system. In agricultural tourism, there are land adoption systems whereupon non-farmers can pay to use agricultural land for a period of time in order to experience the life and work of a farmer [65]. Currently the land adoption system is only available in Jiangjia farmland in Sam Shing Huaxiang (one of the five scenic spots in San Shing Huangxiang). However, the experience is relatively superficial and not well executed.

Protect local residential architecture while maintaining a modern multi-functional aspect. Based on the traditional residential architectural features of Chuanxi, it is important to maintain the use of local materials and traditional design and to provide for multiple functions and values combined with tourism. In this case, a multi-functional approach can enrich visitors' experience by transforming a landscape from something that can merely be viewed, into a multi-dimensional experience by integrating educational, recreational, and purchasable tourism components. The managerial hints are 
that upgrading the function of natural villages, maintaining the rustic style, national and regional cultural characteristics, and at the same time protecting "traditional villages with historical, artistic and scientific values, ethnic minority villages, and residential houses" are very important.

Combine natural and human services to create a visually attractive landscape. Service landscape facilities not only serve to give people access to rural landscapes, they also help increase appreciation of the local environment, especially if there is a focus on natural environment and local characteristics. Substantive investment and major remodeling may not be appropriate. Instead, tourists and residents' basic demands as considered under points $1-4$ and rural image needs to be considered as a priority.

Results of the mixed logit model indicate that more men would prefer a better opportunity to experience rural life by improving characteristics of the local residential landscape, while women would prefer to improve the service landscape. Additionally, tourists with higher levels of education are more interested in seeing improvements to the rural life and productive components of landscapes via increases in field education such as appreciation of the arts and learning crafts activities. Tourists with a higher than average monthly household income are likely to place a higher value on the Sam Shing Huaxiang service landscape and landscape facilities. For example, the higher spending visitors are more willing to bear a higher cost, but their interest in improving the ecological environment is lower, indicating that currently the ecological landscape (as defined in this paper) in Sam Shing Huaxiang has either met these tourists' demands or is not a priority for these tourists. Accordingly, they are likely to be interested in other incentives such as experiencing an "authentic" rural life and productive landscape.

\section{Limitations and Future Research Consideration}

We identified several limitations to this research. First, the timing, as the survey was conducted during August, when the weather is hot and the landscape in Dongli Daisy Garden is not at its optimum. This may have led to some bias in tourists' impressions and their landscape assessment. In a future study, we should consider spreading interview days across different days/times of the week to ensure all populations had an equal opportunity of being interviewed to avoid the effect of small gift incentives bias during on-site sampling [66].

Second, some technical aspects relating to data analysis could be carried out in a more visual way, for example, box plots of WTP for the rural landscape improvements could be presented. Finally, the different attribute levels could be coded for one dummy attribute and then the complete combined test proposed by Poe and Giraud et al. [67] could be used to compare the WTP values for the different attributes before relative importance is assigned and interpretations made.

Author Contributions: Conceptualization, L.C. and Y.Z.; Data curation, L.C., M.-H.C. and J.W.; Supervision, Y.Z.; Validation, M.-H.C.; Visualization, C.-H.S.; Writing-original draft, L.C.; Writing—review \& editing, C.-H.S.

Funding: This research was jointly funded by the National Natural Science Foundation of China, "Study on the Behavioral Characteristics and Regulation Mechanism of Chinese Wildlife Tourists" (No. 41601129); The National Social Science Fund of China, "Research on Public Participation Mechanism in National Park Management" (No. 17BGL122); The Fundamental Research Funds of the Central University, "the Adaptive Management of Ecotourism in National Park" (No. 2015ZCQ-YL-04); Beijing Forestry University, "the Beautiful Chinese Habitat Research Institute Project Funding."

Acknowledgments: The authors thank for David Newsome in Morduch University for expert's suggestions and English polish.

Conflicts of Interest: The authors declare no conflict of interest.

\section{References}

1. Gössling, S.; Lane, B. Rural tourism and the development of Internet-based accommodation booking platforms: A study in the advantages, dangers and implications of innovation. J. Sustain. Tour. 2015, 23, 1386-1403. [CrossRef] 
2. Komppula, R. The role of individual entrepreneurs in the development of competitiveness for a rural tourism destination-A case study. Tour. Manag. 2014, 40, 361-371. [CrossRef]

3. Park, D.-B.; Lee, K.-W.; Choi, H.-S.; Yoon, Y. Factors influencing social capital in rural tourism communities in South Korea. Tour. Manag. 2012, 33, 1511-1520. [CrossRef]

4. Sharpley, R. Rural tourism and the challenge of tourism diversification: The case of Cyprus. Tour. Manag. 2002, 23, 233-244. [CrossRef]

5. Phillips, W.J.; Wolfe, K.; Hodur, N.; Leistritz, F.L. Tourist word of mouth and revisit intentions to rural tourism destinations: A case of North Dakota, USA. Int. J. Tour. Res. 2013, 15, 93-104. [CrossRef]

6. Chen, W. Peasant challenge in post-communist China. J. Contemp. China 1997, 6, 101-115. [CrossRef]

7. Ryan, C.; Gu, H.; Zhang, W. The context of Chinese tourism: An overview and implications for research. In Tourism in China: Destination, Cultures and Communities; Ryan, C., Gu, H., Eds.; Routledge: New York, NY, USA, 2009; pp. 327-336.

8. Deng, J.S.; Wang, K.; Hong, Y.; Qi, J.G. Spatio-temporal dynamics and evolution of land use change and landscape pattern in response to rapid urbanization. Landsc. Urban Plan. 2009, 92, 187-198. [CrossRef]

9. Weng, Y.-C. Spatiotemporal changes of landscape pattern in response to urbanization. Landsc. Urban Plan. 2007, 81, 341-353. [CrossRef]

10. Tian, G.; Liu, J.; Xie, Y.; Yang, Z.; Zhuang, D.; Niu, Z. Analysis of spatio-temporal dynamic pattern and driving forces of urban land in China in 1990s using TM images and GIS. Cities 2005, 22, 400-410. [CrossRef]

11. Liu, Y.; Liu, Y.; Chen, Y.; Long, H. The process and driving forces of rural hollowing in China under rapid urbanization. J. Geogr. Sci. 2010, 20, 876-888. (In Chinese) [CrossRef]

12. Lu, X.H.; Zhu, S.F.; Zhang, Z.H. The empirical analysis on migration scale of rural population between urban and rural areas in China. Chin. Rural Econ. 2006, 25, 35-41. (In Chinese)

13. Fu, B.-J.; Zhuang, X.-L.; Jiang, G.-B.; Shi, J.-B.; Lu, A.Y.-H. FEATURE: Environmental Problems and Challenges in China. Environ. Sci. Technol. 2007, 41,7597-7602. [CrossRef] [PubMed]

14. Gartner, W.C. Rural tourism development in the USA. Int. J. Tour. Res. 2004, 6, 151-164. [CrossRef]

15. Gao, S.; Huang, S.; Huang, Y. Rural tourism development in China. Int. J. Tour. Res. 2009, 11, 439-450. [CrossRef]

16. Campbell, D. Willingness to Pay for Rural Landscape Improvements: Combining Mixed Logit and Random-Effects Models. J. Agric. Econ. 2007, 58, 467-483. [CrossRef]

17. Holmes, T.P.; Adamowicz, W.L.; Carlsson, F. Choice Experiments; Springer: Berlin, Germany, 2017; pp. $133-186$.

18. Johnston, R.J.; Boyle, K.J.; Adamowicz, W.; Bennett, J.; Brouwer, R.; Cameron, T.A.; Hanemann, W.M.; Hanley, N.; Ryan, M.; Scarpa, R.; et al. Contemporary Guidance for Stated Preference Studies. J. Assoc. Environ. Resour. Econ. 2017, 4, 319-405. [CrossRef]

19. Louviere, J.J.; Flynn, T.N.; Carson, R.T. Discrete Choice Experiments Are Not Conjoint Analysis. J. Choice Model. 2010, 3, 57-72. [CrossRef]

20. Daugstad, K. Negotiating landscape in rural tourism. Ann. Tour. Res. 2008, 35, 402-426. [CrossRef]

21. Oppermann, M. Rural tourism in southern Germany. Ann. Tour. Res. 1996, 23, 86-102. [CrossRef]

22. Cawley, M.; Gillmor, D.A. Integrated rural tourism. Ann. Tour. Res. 2008, 35, 316-337. [CrossRef]

23. Devesa, M.; Laguna, M.; Palacios, A. The role of motivation in visitor satisfaction: Empirical evidence in rural tourism. Tour. Manag. 2010, 31, 547-552. [CrossRef]

24. Kneafsey, M. Rural cultural economy tourism and social relations. Ann. Tour. Res. 2001, 28, $762-783$. [CrossRef]

25. Park, D.B.; Yoon, Y.S. Segmentation by motivation in rural tourism: A Korean case study. Tour. Manag. 2009, 30, 99-108. [CrossRef]

26. Pina, I.P.A.; Delfa, M.T.D. Rural tourism demand by type of accommodation. Tour. Manag. 2005, 26, 951-959. [CrossRef]

27. Yagu, R.M. Rural tourism in Spain. Ann. Tour. Res. 2002, 29, 1101-1110. [CrossRef]

28. Sharpley, R.; Roberts, L. Rural tourism-10 years on. Int. J. Tour. Res. 2004, 6, 119-124. [CrossRef]

29. Daugstad, K.; Rønningen, K.; Skar, B. Agriculture as an upholder of cultural heritage? Conceptualizations and value judgements-A Norwegian perspective in international context. J. Rural. Stud. 2006, 22, 67-81. [CrossRef]

30. Lynch, C.; Hack, G. Site Planning, 3rd ed.; The MIT Press: Cambridge, MA, USA, 1998.

31. Naveh, Z.; Lieberman, A.S. Landscape Ecology: Theory and Application; Springer: New York, NY, USA, 1984. 
32. Brown, G. Mapping landscape values and development preferences: A method for tourism and residential development planning. Int. J. Tour. Res. 2006, 8, 101-113. [CrossRef]

33. Tuan, Y.F. Thought and Landscape: The Eye and Mind's Eye. In The Interpretation of Ordinary Landscapes; Meinig, D.W., Ed.; Oxford University Press: New York, NY, USA, 1979; pp. 89-102.

34. Yu, K. Alert and Prevent Damaging Construction in the Name of "the New Rural." Science Times 2006. Available online: http://design.yuanlin.com/HTML/Article/2006-4/Yuanlin_Design_841.HTML (accessed on 8 December 2018). (In Chinese)

35. Li, Y.; Chen, T.; Wang, J.; Wang, H. Research on the tourism urbanization process of rural tourism destination in metropolitan fringe: A case of Beijing city. China Popul. Resour. Environ. 2013, 23, 162-168. (In Chinese)

36. Wang, Y.; Guo, H.; Yang, L. The discussion on evaluation and sustainable development models of traditional villages in western mountainous area of Beijing-A case study of traditional villages in Mentougou District of Beijing. Sci. Geogr. Sin. 2006, 26, 735-742. (In Chinese)

37. Xia, Y. Research and Design of Rural Tourism Area Landscape Planning. Master's Thesis, Southwest Jiaotong University, Chengdu, China, 2006. (In Chinese)

38. Gao, Z.; Wang, Z. Study on rural tourism resources. J. Zhenjiang Coll. 2001, 12, 13-16. (In Chinese)

39. Liu, B.; Wang, Y. Theoretical Base and evaluating indicator system of rural landscape of rural landscape assessment in China. J. Chin. Landsc. Archit. 2002, 18, 76-79. (In Chinese)

40. Wang, Y.; Liu, B. Discussions on rural land-scape and rural landscape planning in China. Chin. Landsc. 2001, 10, 55-58. (In Chinese)

41. Xie, H.; Liu, L.; Li, Z.H. Study on the method of rural landscape evaluation in urban fringe. Geogr. Geo-Inf. Sci. 2003, 19, 101-104.

42. Fang, Y.; Liu, J. Rural landscape changes and its optimization strategies: From the perspective of ideal type narratives. Acta Geogr. Sin. 2012, 67, 1399-1410. (In Chinese)

43. Saxena, G.; Clark, G.; Oliver, T.; Ilbery, B. Conceptualizing integrated rural tourism. Tour. Geogr. 2007, 9, 347-370. [CrossRef]

44. Campbell, D.; Hutchinson, W.G.; Scarpa, R. Using Discrete Choice Experiments to Derive Individual-Specific WTP Estimates for Landscape Improvements Under Agri-Environmental Schemes: Evidence from the Rural Environment Protection Scheme in Ireland. 2006. Available online: https://ideas.repec.org/p/fem/femwpa/ 2006.26.html (accessed on 8 December 2017).

45. Bergland, O. Valuation of landscape elements using a contingent choice method. In Proceedings of the 1997 European Association of Environmental and Resource Economists Conference, Tilburg, The Netherlands, 26-28 June 1997; pp. 45-48.

46. Hanley, N.; Wright, R.E.; Alvarez-Farizo, B. Estimating the economic value of improvements in river ecology using choice experiments: An application to the water framework directive. J. Environ. Manag. 2006, 78, 183-193. [CrossRef]

47. Birol, E.; Karousakis, K.; Koundouri, P. Using a choice experiment to estimate non-use values: The case of Cheimaditida wetland, Greece. Water Sci. Technol. 2005, 5, 125-133. [CrossRef]

48. Domínguez-Torreiro, M.; Soliño, M. Provided and perceived status quo in choice experiments: Implications for valuing the outputs of multifunctional rural areas. Ecol. Econ. 2011, 70, 2523-2531. [CrossRef]

49. Colombo, S.; Hanley, N. How can we reduce the errors from benefits transfer? An investigation using the choice experiment method. Land Econ. 2008, 84, 128-147. [CrossRef]

50. Carson, R.T.; Czajkowski, M. A new baseline model for estimating willingness to pay from discrete choice models. J. Environ. Econ. Manag. 2019, 95, 57-61. [CrossRef]

51. Bronnmann, J.; Asche, F. Sustainable seafood from aquaculture and wild fisheries: Insights from a discrete choice experiment in Germany. Ecol. Econ. 2017, 142, 113-119. [CrossRef]

52. Kim, D.; Park, B.J.R. The moderating role of context in the effects of choice attributes on hotel choice: A discrete choice experiment. Tour. Manag. 2017, 63, 439-451. [CrossRef]

53. Wehrli, R.; Priskin, J.; Demarmels, S.; Schaffner, D.; Schwarz, J.; Truniger, F.; Stettler, J. How to communicate sustainable tourism products to customers: Results from a choice experiment. Curr. Issues Tour. 2017, 20, 375-1394. [CrossRef]

54. Ayala, D.A.; Hoyos, D.; Mariel, P. Landscape Valuation through Discrete Choice Experiments: Current Practice and Future Research Reflections. 2012. Available online: https:/addi.ehu.es/bitstream/handle/10810/ 8011/2012.03.pdf?sequence=6\&isAllowed=y (accessed on 19 February 2018). 
55. Hess, S.; Train, K. Correlation and scale in mixed logit models. J. Choice Model. 2017, 23, 1-8. [CrossRef]

56. Gebben, D.J. An Attribute Based of Recycling Preferences at Michigan State University. Master's Thesis, Michigan State University, East Lansing, MI, USA, 2008.

57. Kuminoff, N.V.; Parmeter, C.F.; Pope, J.C. Which hedonic models can we trust to recover the marginal willingness to pay for environmental amenities? J. Environ. Econ. Manag. 2010, 60, 145-160. [CrossRef]

58. Hanemann, W.M. Welfare Evaluations in Contingent Valuation Experiments with Discrete Responses. Am. J. Agric. Econ. 1984, 66, 332-341. [CrossRef]

59. Borah, B.J. Econometric Models of Provider Choice and Health Care Use in India. Ph.D. Thesis, Indiana University, Bloomington, IN, USA, 2006.

60. Revelt, D.; Train, K. Customer-Specific Taste Parameters and Mixed Logit. 2000. Available online: https: //eml.berkeley.edu/wp/train0999.pdf (accessed on 12 January 2019).

61. Krinsky, I.; Robb, A.L. On approximating the statistical properties of elasticities. Rev. Econ. Stat. 1986, 64, 715-719. [CrossRef]

62. Pan, S. The Driving Mechanism of Rural Tourism and the Development Mode of China. Master's Thesis, Northeast Normal University, Changchun, China, 2007. (In Chinese)

63. Fleischer, A.; Pizam, A. Rural tourism in Israel. Tour. Manag. 1997, 18, 367-372. [CrossRef]

64. Sharpley, R.; Jepson, D. Rural tourism: A spiritual experience? Ann. Tour. Res. 2011, 38, 52-71. [CrossRef]

65. Garrod, B.; Wornell, R.; Youell, R. Re-conceptualising rural resources as countryside capital: The case of rural tourism. J. Rural. Stud. 2006, 22, 117-128. [CrossRef]

66. Howley, P. Landscape aesthetics: Assessing the general publics' preferences towards rural landscapes. Ecol. Econ. 2011, 72, 161-169. [CrossRef]

67. Poe, G.L.; Giraud, K.L.; Loomis, J.B. Computational Methods for Measuring the Difference of Empirical Distributions. Am. J. Agric. Econ. 2005, 87, 353-365. [CrossRef]

(C) 2019 by the authors. Licensee MDPI, Basel, Switzerland. This article is an open access article distributed under the terms and conditions of the Creative Commons Attribution (CC BY) license (http://creativecommons.org/licenses/by/4.0/). 